\title{
DÍAZ HERNÁNDEZ, Onésimo, Expansión. El desarrollo del Opus Dei entre los años 1940 y 1945, Rialp, Madrid, 2020, 692 pp.
}

No es fácil hacer la historia de una institución desde dentro. Más aún si se trata de una entidad religiosa, con la particular autocomprensión que supone la pertenencia a este tipo de organismos. Es el caso del Opus Dei, la organización católica en cuya evolución histórica se centra este libro. Su autor, Onésimo Díaz, doctor en Historia Contemporánea por la Universidad del País Vasco, es profesor de la Universidad de Navarra. A este respecto, Feliciano Montero, principal experto en historia religiosa contemporánea española, resumió así en 2017 la historiografía sobre el Opus Dei: «Los estudios críticos (algo panfletarios) de los años 60 fueron seguidos en los 90, de estudios oficiales, por parte de historiadores de la Institución, en el contexto del proceso de beatificación del fundador Escrivá de Balaguer. Recientemente la Institución ha iniciado la investigación histórica de la Institución desde sus orígenes, creando para ello un centro de investigación vinculado al Archivo General de la Prelatura, un equipo de una revista. Se trata de un proyecto específicamente historiográfico, elaborado profesionalmente, pero quizá aún desde una perspectiva demasiado interna».

El libro de Onésimo Díaz forma parte de ese esfuerzo, centrándose en la historia de la institución durante la II Guerra Mundial. Es una historia escrita con metodología historiográfica, hecha desde dentro, tal y como reflejan las fuentes utilizadas, y abordada con honestidad. Para empezar, el aporte documental procedente del propio Archivo del Opus Dei es impresionante. Y dado que ese archivo interno aún no está ordenado ni abierto a los investigadores, solo el haber hecho públicos esos documentos es ya una gran aportación. Esta documentación se completa con la procedente de otros centros (como el Archivo General de la Administración) y con testimonios orales. Sin embargo, tal y como señala el propio autor, habría sido interesante añadir otros archivos, como el de la Compañía de Jesús o las Congregaciones Marianas, que hubieran aportado visiones complementarias. En cuanto a la bibliografía, sorprende positivamente el esfuerzo por citar y utilizar una ingente cantidad de obras, no solo de historia del Opus Dei o de la Iglesia en España en esa época, sino también sobre el contexto español y europeo.

La honestidad a la que antes hacía referencia se refleja en esta bibliografía, que incluye obras críticas con el Opus Dei, pero también en el contenido del libro. En sus páginas, junto a los logros de la institución en esos años (extensión de sus labores, incremento del número de miembros, primeras aprobaciones eclesiásticas, etc.) no faltan los problemas, las críticas o los nombres de personas que abandonaron el Opus Dei, incluyendo algunos que posteriormente hicieron pública su memoria negativa sobre esta etapa. El autor, en vez de esconder o pasar por encima de estas cuestiones, no ha dudado en aportar documentación sobre ellas, lo que permite hacerse una idea ajustada a la realidad de lo que fueron aquellos años para el Opus Dei. 
En general, fue una etapa positiva, de expansión, tal y como indica el título del libro, con un crecimiento circunscrito a España, por culpa de la Guerra Mundial y de la autarquía franquista, aunque pensara ya en expandirse fuera de sus fronteras. Hitos de este crecimiento fueron el apoyo del obispo de Madrid, el visto bueno del Vaticano al ordenamiento jurídico del Opus Dei en 1943 y la ordenación sacerdotal de los primeros miembros de la institución, en 1944. Díaz explora las causas de esta expansión, en el contexto de la España de la posguerra, y llama la atención sobre «la libertad vivida por los miembros del Opus Dei en un régimen dictatorial» como el franquista. Destaca, por ejemplo, la participación de algunos de ellos en una organización clandestina catalanista, mientras otros se situaban en torno a las diversas familias franquistas, que entonces se estaban conformando. Documenta también cómo el propio Escrivá frenó la iniciativa de una persona próxima al Opus Dei de «animar a todos a apuntarse al sindicato falangista para influir cristianamente en esta organización», pues contrasta con el ambiente monolítico de la España de la posguerra. Llama la atención el diferente ambiente vivido entre los miembros del Opus Dei en Madrid y en Barcelona, donde el catalán era el idioma habitual de comunicación entre sus socios, incluso por escrito, pese a las restricciones idiomáticas impuestas por la dictadura en la posguerra. Destaca asimismo la relación que tuvieron con el Opus Dei jóvenes que en el futuro tendrían una actividad destacada en la cultura o en la política española, como Luis Martín-Santos o Josep Benet.

En cuanto a los problemas, se resalta que el Opus Dei tuvo que lidiar en la primera mitad de los años cuarenta con tres frentes críticos: el eclesiástico, el universitario y el político. En el primer campo, la institución mantuvo en general buenas relaciones con el episcopado y con la mayor parte de las órdenes religiosas, aunque a la vez surgieron prevenciones, relacionadas con la novedad del mensaje de santidad en medio del mundo, que para algunos eclesiásticos era una auténtica herejía, o con el hecho de que la nueva entidad pescara vocaciones en campos habitualmente reservados a otras, tal y como sucedió con las Congregaciones Marianas. En el ámbito universitario, se aportan datos y nombres exactos sobre la idea, tan extendida, de «la conquista de las cátedras» por parte del Opus Dei: en concreto, quince miembros obtuvieron cátedras en las universidades españolas en estos años (un 8,37 \% de los nuevos catedráticos). Se trata de «porcentajes no muy elevados, aunque sí significativos», en el contexto de la obligada renovación de la universidad, tras la depuración y el exilio de muchos profesores. Por último, a nivel político resalta la inquina de ciertos sectores de Falange contra el Opus Dei, que dieron lugar a varios informes confidenciales, con el peligro que ello suponía en plena dictadura. El de 1942 concluía: «Esta organización se opone a los fines del Estado. 1) Por su clandestinidad. 2) Por su carácter internacionalista. 3) Por la intromisión que supone en la vida intelectual y en el orden de ideas propugnado por el Caudillo». Ciertas habladurías de aquellos años suenan hoy a risa, aunque no lo eran en el ambiente opresivo de la dictadura franquista 
durante la II Guerra Mundial. Por citar solo un ejemplo, algunos consideraban sus iniciativas «un núcleo de propaganda yanqui», lleno de «espías y propagandistas clandestinos de USA. Tenemos nuestras bicicletas - lo cual es "costumbre yanqui"-, tenemos relaciones con el consulado de Estados Unidos y fumamos tabaco rubio».

Esta y otras cuestiones son contadas por el autor a modo de microhistoria, reproduciendo muchos documentos originales. Él mismo reconoce que la abundancia de datos y nombres puede hacer el relato poco «fluido por la información copiosa que deseo mostrar». Efectivamente, hay tanta información que a veces el libro se hace difícil de leer. No obstante, al tratarse de un tema completamente inédito, sobre el que tantas veces se ha escrito más desde el tópico que desde las fuentes, el libro merece la pena. Es, en ese sentido, un punto de partida para futuras obras de síntesis, que sigan profundizando en la historia académica y documentada del Opus Dei, alejándose tanto de apologías como de invectivas.

Santiago de Pablo 